\title{
An Introduction to the System of Appeals in Iran, Egypt and France
}

\author{
Rasoul Maghsoudpour ${ }^{1} \&$ Malihe Yavari Tamam ${ }^{1}$ \\ ${ }^{1}$ Department of Law, Mashhad Branch, Islamic Azad University, Mashhad, Iran \\ Correspondence: Rasoul Maghsoudpour, Department of Law, Mashhad Branch, Islamic Azad University, \\ Mashhad, Iran. E-mail: Maghsoudpour@gmail.com
}

Received: August 22, 2019

Accepted: December 30, 2019 Online Published: July 3, 2020

doi:10.5539/ilr.v9n1p72

URL: https://doi.org/10.5539/ilr.v9n1p72

\begin{abstract}
The present study aims at exploring the system of appeals in Iran, Egypt and France in order to gain a better understanding of those systems. Firstly, the French legal system is explored. The organization of the French courts consists of the Court of First Instance, the Court of Appeal, and The Cour de Cassation. Under the French legal system, there are a few specific rules concerning appeal from judgment and appeal from other factors. Secondly, the Egyptian legal system as a codified law system was considered. It consists of three courts of First, Instance and Cassation. In fact, the Egyptian court of Appeal reconsiders felony cases. In general, the Egyptian Courts of appeal include eight courts and each court is independent and hears specific kinds of Claims such as economical and criminal matters. Thirdly, Iranian appeal system such as its deadline, effects and types is examined.
\end{abstract}

Keywords: appeals, Court, Egypt, Iran, France

\section{Introduction}

\subsection{Comparison of Systems}

The French legal system has origins in Roman law and is on the basis of codified laws. The organization of the French courts consists of the Court of First Instance, the Court of Appeal, and The Cour de Cassation.

\subsection{The court of First Instance}

The courts of first instance are as following. The civil court (tribunal de grande instance) concerns with many issues such as family disputes, property leases and civil actions for defamation. The district court (tribunal d'instance) is a judicial lower court, which hears civil suit cases such as disputes with neighbors. Other first instance courts are the commercial courts (tribunaux de commerce). They are the oldest courts in the French, creating at the end of the middle Ages. The commercial court hears commercial cases such as litigation between traders or between traders and commercial companies. In general, these courts are "composed of non-professional judges, called "consular judges" (abergel-associes, 2019). They are volunteers, chosen from trades people or business leaders and elected by them". In France, the labor court (conseil de prud'hommes) resolves the disputes related to employment contracts. In fact, these disputes are resolved by "judges who are elected from the business community based on their commercial expertise and their legal experience" (Paris City of Law, 2018). In Courts of Appeal, "The aim of the appeal is, by challenging the judgment issued by a first-instance court, to obtain that it be reformed or overturned by the Court of Appeal" (French Code of civil procedure, new article 542) (Marie Danis Maxime Cléry-Melin, 2017). The appeals procedure "set out by the Code of Civil Procedure. So, Solicitors are able to represent a client in the jurisdiction" and ask the court of appeal to "reopen an appeal which it had already determined in order to avoid real injustice in exceptional circumstances" (O'Hanlon, 2002). The Court of cassation (the Cour de Cassation) as the highest court in the French legal system hears criminal, social and civil disputes. It has the power to reconsider the decisions made by the lower court in order to make sure that the law is applied correctly. The main aim of the Cour de Cassation is "rather to ensure a uniformity of the interpretation of the law among all the French courts" (Encyclopædia Britannica, 2019). As well, it is the single court in France that tries "to achieve uniformity of interpretation for the whole Republic" (courdecassation, 2019).

\subsection{The French System of Appeals}

The French appellate scheme is included in the Nouveau Code De Procedure Civile (the Code of Civil 
Procedure). Articles 543, 544, and 545 relate to the system of appeals. Under the French legal system, there are a few specific rules concerning appeal from judgment and appeal from other factors. The former consists of exceptions d'incompetence such as contredit and appeal and the latter refers to the disqualification of judges and experts or decisive oaths.

Exceptions d'incompetence is called the choice of forum (Baker, 1984). Sometimes, the appellate court reviews it in order to solve the probable jurisdictional problems (contredit). Its procedure will be start within two weeks of the lower court judgment, though it takes 30 days from the judgment date for taking an appeal. The contredit procedure is not able to deal with all jurisdictional issues. Therefore, the appellate court enters judgment. On the other hand, when a judge or an expert is interested in a special case or is related to a special party, the court of appeals takes an appeal in order to have the judge to accept to disqualify himself. As well, one of the parties may try to take an advantage of a special written power of attorney or false testimony, this action is called a deceive oath.

\subsection{The Egyptian Legal System}

In Egypt, the legal system is considered as a codified law system (Abdel Wahab, 2006). This system is based on Islamic (Shariah) law and Napoleonic Code. That is, its legal code stems from the Napoleonic code and the legal and judiciary system in Egypt derives from the French legal system. (Global Ethics Observatory, 2019). In fact, the Egyptian government does not intervene in judicial system and it is an independent source (wikipedia, 2018). Article 165 provides: The judiciary shall be independent. It shall be exercised by courts of justice of different types and forms which shall issue their judgments in accordance with the law. Article 167 provides: The law shall determine the organization of the judiciary and its functions and the way in which it is established and shall prescribe the conditions and procedures concerning the appointment and transfer of its members. Article 173 provides: Every judicial body shall manage its own affairs. "As a general rule, Egyptian judges respond very negatively to any outside attempt to influence their rulings, making any such attempt almost certainly counter-productive due to the likely backlash. Alignment of interests with the executive branch on certain issues at various times should not be confused with executive control" (Egypt Judiciary - An Overview, 2019). Article 166 provides: Judges shall be independent and be subject to no other authority but the law. No outside authority may intervene in court cases or judicial matters. Article 168 provides: The judges may not be dismissed from office. The law shall determine the disciplinary measures which may be applied to them.

The Egyptian Court system consists of three courts of First Instance, Appeal and Cassation (Egyptian Legal System in brief) and its structure is under the supervision of the Judicial Authority Law (Law No. 46 of 1972), the Criminal Procedure Code (Law No. 150 of 1950), and the Civil and Commercial Procedure Code (Law No. 13 of 1986). (The Tahrir Institute for Middle East Policy, 2019).

\section{Court of Cassation}

The Court of Cassation was built "to provide exclusive and uniform interpretation and application of the law" in 1931 (The Tahrir Institute for Middle East Policy, 2019). It hears challenges and cases related to public prosecution or adversary. This court examines the lawsuits and claims that emerged from a judge's action. "The Court of Cassation is defined by Articles 2-5 of the Judicial Authority Law. The Court of Cassation has its own prosecutorial office established by Article 24 of the Judicial Authority Law" (The Tahrir Institute for Middle East Policy,2019).

\subsection{Court of Appeal}

Courts of Appeal review the decisions made by courts of first instance in civil cases. They reconsider felony cases. A panel of three judges hears the cases in each criminal court. Courts of Appeal consist of eight courts called Alexandria, Assiut, Beni Suef, Cairo, Ismailia, Qena, Mansoura, and Tanta. Each court is independent and hears specific kinds of claims, for example, special cases related to economy, trade or crime. On the other hand, the court of cassation has jurisdiction over decisions made by a court of appeal and is able to grant appeal if the court's ruling is inadequate in its reasoning. The courts of appeals are defined by Articles 6-8 of the Judicial Authority Law. According to Article 14: Right to equality before courts and tribunals and to a fair trial: "a higher tribunal has jurisdiction over review of conviction and sentence based on new and proper evidence and the law takes into consideration the nature of the case.

\subsection{Courts of First Instance}

It has jurisdiction over small and large claims and petty offences. In General, a panel of three judges hears appeals to the verdicts in the case of small claims and the court of first instance is responsible. A panel of three judges examines civil matters involving large claims in the court of appeal. "The courts of first instance are 
defined by Articles 9-11 of the Judicial Authority Law" (The Tahrir Institute for Middle East Policy, 2019).

\section{The Iranian System of Appeals}

\subsection{Appeals and Appealable Verdicts}

Iranian Article 366 provides that "Appeal is to determine whether or not the issued verdicts are in conformity with religious rules and regulations" (Mohseni, 2016).

The most important appeals are as followings (Hasanzadeh, 2014):

1) Verdicts requiring more than twenty million riyals.

2) Verdicts related to marriage and its revocation, divorce, devotion

\subsection{Appeal Deadline}

Article 397- The deadline for appealing to persons residing in Iran is twenty days and for persons residing abroad for two months.

Article 398 - The beginning of the appeal period is as follows:

(A) For orders and appealable verdicts issued by the Court of Appeal from the date of notification.

(B) For orders and reviewable verdicts issued by Trial Court that have not been appealed since the expire of the revision deadline.

\subsection{Appellants}

According to Article 378 of the Code of Civil Procedure, litigants, their legal representatives, and their attorneys and the Attorney General of the country may appeal.

\subsection{Effects of Appeals}

Having a transitional effect means that the case will be re-judged in all its jurisdictional and subject matters. Appeals do not have a transitional effect as opposed to revision, because the Supreme Court is not the Third Reference Court to hear the case again.

\subsection{Suspension Effect}

Appeal, as one of the extraordinary methods of objecting to the verdicts, will not have a suspensive effect on the issued verdicts unless the accused is convicted to non-financial crimes, in which the verdicts will be suspended. Suspension of a verdict is subject to two conditions: first, when the enforcement action has begun but not terminated, second, when the convict requests that the issued verdicts be stopped.

\subsection{Types of Appeal}

Appeal can be divided into the following types by two different criteria;

(A) Appeal within the fixed deadline

This type of appeal is usually done by a convict. If an appealable verdict is issued against each of the parties, each may appeal within the fixed deadline. This type of appeal is called the main appeal.

(B) Appeal outside the fixed deadline

If the appealable verdict is not appealed within the fixed deadline, or for any reason the appeal is dismissed and finalized, the claimant can claim that the verdict does not comply with the law and Sharia and he is able to appeal through the Attorney General of the State (Hasanzadeh, 2018).

Article 380 - The petition shall contain the following:

1) First name, last name, place of residence and other characteristics of the appellant or his lawyer.

2) First name, last name and residence and other characteristics of the other party.

3) The order or verdict from which the apeal is made.

4) The court issuing the verdict

5) Date of notification of verdict

6) Reasons to appeal.

\subsection{Violations}

Article 371-the verdict will be violated in the following cases: 
1) When the court issuing the verdict does not have the inherent jurisdiction to hear the case.

2) When the issued verdict is contrary to religious law and regulations.

3) Failure to comply with the principles of procedure and the rules of law

4) Different opposing verdicts have been issued without any legal reasons in a case between the parties.

5) Investigations are incomplete in the case or their reasons or documents (parties) have not been taken into account by the judge.

\section{Conclusion}

Even the best judge is always subject to error and mistake. Thus, there are ways in which the issued verdicts can be reviewed in judicial proceedings. This review is done in the form of an appeal against a verdict (Gholizadeh, 2016). In fact, when a case is heard by a court in a case, one party tries to complain and make an appeal against the verdict and wants to change the final decision. In other words, Appeal is one of the unique methods of appealing legal verdicts and aims to identify the conformity of the verdict with the law and the Sharia (Iranian Rule 366 Civil Procedure). This meaning of the appeal is reiterated in Article 2 of the French Civil Procedure Code: The purpose of the appeal is to issue a ruling by the Supreme Court on verdicts that are contrary to the rule of law. Accordingly, "if the verdict is issued and finalized, it can be appealed in France. As well, the Egyptian legal system has borrowed from the French legal system in respect of various institutions and concepts. However, there is a marked difference in terms of controls over the constitutionality of laws" (El Chazli, F \& El Chazli, K, 2010). Articles $6-8$ of the Judicial Authority pay attention to the Courts of appeal in Egypt. These courts hear special cases related to economy, trade and crime.

\section{References}

Abdel Wahab, M. (2006). An Overview of the Egyptian Legal System and Legal Research. Retrieved from https://www.nyulawglobal.org/globalex/Egypt.html

Abergel-Associes. (2019). Court of Commerce of Paris. Retrieved from https://abergel-associes.com/en/court-commerce-paris/

Courdecassation. (2019). The Court of cassation. Retrieved from https://www.courdecassation.fr/about the_court_9256.html

Egypt Justice. (2019). Egypt Judiciary - An Overview of branches of the Egyptian judiciary. Retrieved from https://egyptjustice.com/egypt-judiciary-an-overview

El Chazli, F., \& El Chazli, K. (2010). Egypt: The independence of the Judiciary. Retrieved from https://euromedrights.org/wp-content/uploads/2018/03/EGYPT-The-independence-of-the-Judiciary-EN.pdf

Encyclopædia Britannica. (2019). Cour de Cassation. Retrieved from https://www.britannica.com/topic/Cour-de-Cassation

Gholizadeh, A. (2016). An Analysis of the Unity of Proceedings` Principles in the Code of the Civil Procedure. Knowledge of civil rights, 2(3).

Global Ethics Observatory. (2019). The Egyptian Legal System. Retrieved from http://www.unesco.org/shs/ethics/geo/user/?action=Geo4Country\&db=GEO4\&id=9\&lng=en

Hasanzadeh, M. (2014). The Comparison of review, appeals and trail. Law Studies Journal, 3(4).

Marie Danis Maxime Cléry-Melin. (2017). Entry into force of new rules governing appeals: what you need to know. $\quad$ Retrieved from https://www.august-debouzy.com/fr/blog/1055-entry-into-force-of-new-appeals-rules-in-france-what-you-n eed-to-know

Mohseni, H. (2016). Appeal: Judicial Oversight over the First Instance Judgment. Judgmental procedure Journal, $1(2)$.

O'Hanlon, K. (2002). Court of Appeal - Jurisdiction - Application to reopen appeal - Whether Court of Appeal having power to reopen appeal after final judgment given and drawn up. Retrieved from http://www.uniset.ca/other/cs2/20002AER353.html

Paris City of Law. (2018). Efficient, predictable and accessible like no other. Retrieved from https://www.parisplacededroit.org/images/pdf/BDP_BROCH_PARIS_PDD.pdf

The Tahrir Institute for Middle East Policy. (2019). Egypt's Court System 101. Retrieved from 
https://timep.org/transitional-justice-project/egypts-court-system-101/

Wikipedia (2018). Judiciary of Egypt. Retrieved from https://en.wikipedia.org/wiki/Judiciary_of_Egypt

\section{Copyrights}

Copyright for this article is retained by the author(s), with first publication rights granted to the journal.

This is an open-access article distributed under the terms and conditions of the Creative Commons Attribution license (http://creativecommons.org/licenses/by/4.0/). 